\title{
THE PROCESS AND PRINCIPLES OF INTESTINAL STOMA SITING
}

\author{
Katarzyna Gaćkowska ${ }^{1 \mathrm{~A}, \mathrm{~B}, \mathrm{C}, \mathrm{D}, \mathrm{F}}$, Monika Pruchniak ${ }^{1 \mathrm{~A}, \mathrm{C}, \mathrm{D}, \mathrm{E}, \mathrm{F}}$, Anna Śmiżewska ${ }^{2 \mathrm{~B}, \mathrm{C}, \mathrm{E}, \mathrm{F}}$
}

${ }^{1}$ Chair of Interventional Nursing, Department of Surgery and Surgical Nursing, Faculty of Health Sciences, Medical University of Lublin, Poland

${ }^{2}$ Stoma Care Clinic, Provincial Specialist Hospital in Wroclaw, Poland

Authors' contribution:

A. Study design/planning • B. Data collection/entry $\bullet$ C. Data analysis/statistics $\bullet$ D. Data interpretation $\bullet$ E. Preparation of manuscript $\bullet$ F. Literature analysis/search $\bullet$ G. Funds collection

\author{
Address for correspondence: \\ Katarzyna Gaćkowska \\ Chair of Interventional Nursing \\ Department of Surgery and Surgical Nursing \\ Faculty of Health Sciences \\ Medical University of Lublin \\ Poland \\ e-mail: katarzyna.gackowska@umlub.pl \\ SUBMITTED: 5.12 .2021 \\ ACCEPTED: 2.01.2022 \\ DOI: https://doi.org/10.5114/ppiel.2021.113789
}

\begin{abstract}
Intestinal stoma site selection is one of the key elements in preoperative planning and nursing care of patients with intestinal diseases. It is a medical procedure that should be performed prior to any scheduled surgery potentially resulting in a stoma. In emergency surgeries this could be difficult, but an attempt should always be made. Preoperative stoma site selection allows the optimal creation and location of the stoma. The priority is that the stoma should be easily accessible and visible to the patient. A correctly located stoma reduces postoperative complications and improves patients' quality of life.

This work discusses the process and principles of selecting the intestinal stoma site in adult patients prior to scheduled or emergency surgeries. It includes a review of the current literature on this subject. The analysis involved scientific publications from the period between 1 January 2000 and 31 August 2021. Literature searches were conducted in the PubMed and Google Scholar databases, using a mixed combination of the following English and Polish terms: "ostomies", "intestinal stoma”, "education", "stoma site selection”, "stoma site marking", "stoma siting", "stoma complications", "peristomal skin complications”, "stomia jelitowa”, "model opieki”, "edukacja”, "wyznaczanie miejsca stomii", and "powikłania stomijne". Sixty scientific publications were used to analyse the subject matter of this work.
\end{abstract}

Key words: intestinal stoma, education, stoma site selection, stoma site marking, stoma complications.

\section{INTRODUCTION}

Intestinal stoma is a surgically created connection between the large or small intestine and the patient's abdominal wall. Intestinal stomata are divided into faecal and feeding stomata. They can be formed permanently or temporarily. Definitive stomata are usually an integral and planned part of the surgical procedure. They are formed mainly in patients with removed sphincter apparatus or with permanent sphincter damage. Temporary stomata are taken down once physiological bowel movement is restored. This type of stoma is considered to be a step in the treatment of the primary disease. The names of the types of stomata are derived from the section of the gastrointestinal tract in which the opening is formed: the large intestine - colostomy; the small intestine ileostomy [1-4].

A common indication for intestinal stoma is colon cancer. Scheduled surgeries involving the formation of intestinal stomata are also performed in patients with Crohn's disease and ulcerative colitis, as well as familial multiple polyposis, complicated diverticu- losis, and in cases requiring peripheral gastrointestinal decompression. The most common indications for emergency stoma procedures include mechanical abdominal injury, acute intestinal obstruction, and gastrointestinal perforation $[1,5,6]$.

In 1967 Turnbull and Weakley presented the principles of producing a "good stoma", which are still applicable today. These include the following: correct location, properly prepared stoma canal in the abdominal walls, no bowel tension (especially where the bowel is attached to the skin), attaching the mesentery to the abdominal wall (avoiding vessels), folding the mucosa of the stoma and attaching it to the skin, and adequate blood supply to the bowel. These principles should also include correct stoma height, depending on its type. Ileostomies and urostomies should be $2-4 \mathrm{~cm}$ high, and a colostomy they should be $0.5-1.5 \mathrm{~cm}$ high. It is also important to provide appropriate, personalised, and high-quality stoma equipment as early as at the operating table. This equipment should be selected according to the following criteria: tightness for stool and gas, biological neutrality, ease of use, and aesthetics [7]. 
Prof. Roman Góral was a pioneer of the stoma movement in Poland. In 1987 he founded the Polish Society for Stoma Patient Care (POL-ILKO). A year later the Polish Coloproctology Club was established on his initiative. In 2002 the "Stoma Patient Care Model" was published and implemented in clinical practice in Poland. The importance of pre-operative education and stoma-care continuity throughout follow-up nursing and education in the early postoperative period at hospitals and later in outpatient stoma (proctology) clinics were the central premises underlying this model, which has been in use until today. One of its main assumptions was that stoma sites should be marked pre-operatively [8-11]. Other tasks of the nursing personnel or physician in the preoperative care of the patient are presented in Table $1[8,9]$.

Selecting the intestinal stoma site is one of the key elements in preoperative planning and nursing care of patients with intestinal diseases. This should be a standard procedure performed before every scheduled or emergency surgery in patients with intestinal diseases and disorders. It is easier and more effective for each patient to manage a stoma that is

Table 1. The tasks of the nursing personnel or physician in the preoperative care of a patient who is about to undergo a stoma surgery

1. Talking to the patient about the anatomical and physiological changes following the scheduled stoma creation surgery

2. Presenting the technique, appearance, and action of the stoma

3. Discussing the potential postoperative and stoma-related complications

4. Discussing changes in various aspects of the patient's quality of life related to stoma creation, such as physical appearance, self-esteem, state of health, sexual life, professional activity, social and academic activity, entertainment and leisure choices

5. Presenting the diet required after stoma creation

6. Providing emotional support and advice

7. Providing the patient with information materials about stoma self-care and maintenance

8. Teaching the patient breathing and isometric exercises and effective coughing, which significantly reduce the risk of postoperative thromboembolic complications

9. Performing tests, correcting water-electrolyte and/or nutritional imbalance

10. Selecting the stoma creation site

11. Cleaning the gastrointestinal tract of faecal mass according to the procedure adopted in a given hospital (considering the patient's age and circulatory disorders)

12. Evaluating the psychological condition of the patient, taking into account his or her response to the scheduled stoma surgery (fear, aggression, denial)

13. Evaluating the potential participation of family members in postoperative care properly located. This facilitates rehabilitation and expedites recovery [8-10, 12].

The ideal scenario is when the future stoma site is marked by a qualified stoma care nurse (male nurse) following consultation with the physician-surgeon and with the active participation of the patient [8-10, 12-18]. The stoma site can be selected several days before the surgery, in an outpatient setting, e.g. during a visit at a stoma care clinic [15]. This gives the healthcare team considerable freedom in determining the optimal stoma location. In most cases, however, the stoma location is marked in the hospital the day before the surgery, in a surgical dressing room. This should also be the time to start educating the patient and to provide initial training in self-care and using stoma equipment. The purpose of these actions is to mentally and physically prepare the patient for surgery. This may result in earlier discharge from hospital after the surgery and improve the effectiveness of postoperative nursing care [7-9, 12, 19-29].

For emergency surgeries, the stoma site is usually marked by the surgeon during the operation. Creating a stoma in a correct location primarily depends on the physician's experience and the course of the surgery $[14,18]$. There are clinical situations in which the patient does not cooperate with the physician, has a very bloated stomach, or experiences severe pain [30]. The risk of improper stoma location usually affects obese and post-operative patients, as well as those with abdominal wall hernia or pathological skin lesions. In the case of these patients, there are limited possibilities to mark the appropriate stoma location while in surgery [31]. In some instances, the anatomical conditions in the abdominal cavity make it impossible to form the stoma in the planned location. Usually, this leaves the surgeon-physician with no choice but to make an opening in another, accessible location (this is called a forced stoma) [30, 31].

An inappropriately formed and improperly located stoma involves a high rate of local complications in both the short-term and long-term post-operative period. In the short term, potential complications include bleeding, infections around the stoma, ischaemia, necrosis, and stoma retraction. In the long term, the most common post-operative complications include parastomal hernia, stoma stricture, or stoma prolapse. Cancer recurrence and Crohn's disease relapse are also possible [32-35]. Local complications usually involve bacterial infections and skin inflammation caused by irritation [31, 36-38].

Stoma formation is associated with changes in body image, potentially causing discomfort for the patient. If the stoma is improperly located, the patient requires assistance in stoma care. Stoma patients' self-esteem is low, they withdraw socially, and become apathetic and depressed. These factors combined reduce the patient's quality of life [30, 39-41]. 


\section{AIM OF THE STUDY}

This work discusses the process and principles of selecting the intestinal stoma site in adult patients prior to scheduled or emergency surgeries. It does not include information on marking the intestinal stoma site in children.

\section{MATERIAL AND METHODS}

The analysis involved scientific publications from the period between 1 January 2000 and 31 August 2021. Literature searches were conducted in the PubMed and Google Scholar databases, using a mixed combination of the following English and Polish terms: "ostomies", "intestinal stoma", "stoma site selection", "stoma site marking”, "stoma siting", "stoma complications", "peristomal skin complications", "stomia jelitowa”, "model opieki”, "wyznaczanie miejsca stomii", and "powikłania stomijne". A total of 1101 publications were found.

Having read the titles, abstracts, and keywords, the authors initially selected 297 items from among these. After reading and analysing the content of the selected publications in terms of their relevance to the subject matter and objective of this work, the authors rejected 237 of them. Ultimately, 60 scientific publications were used to analyse the subject matter of this work. It includes photographs presenting the actions of a nurse selecting the intestinal stoma site and photographs depicting patients with incorrectly located intestinal stoma.

\section{SELECTING THE STOMA SITE WITH THE PATIENT IN VARIOUS POSTURES}

All actions in the process of selecting the intestinal stoma site should be performed carefully and without undue haste [27]. During stoma site selection, the examined part of the patient's body should not be covered by clothing. The stoma site should be selected and initially marked successively in lying, standing, and sitting positions. It is also recommended to modify the standing and sitting postures by bending the patient forward [14, 15, 18, 42]. For patients in wheelchairs, e.g. due to paraplegia, the stoma site is selected in the position the patient is in $[16,42]$.

Examining the patient in a lying position allows identification of the surgical field for the future intestinal stoma [18]. Examining the patient's body in various positions allows identification of areas that are not suitable for ostomy and facilitates making potential corrections to the previously selected site [15]. The priority is for the intestinal stoma site to be easily accessible and visible to the patient [13, 15, 18, 42]. An intestinal stoma must not limit the patient's movements, which would interfere with the correct maintenance of stoma appliances. That is why before the final selection of the stoma site, the patient should have the opportunity to try the stoma appliance dedicated to him or her [17, 43-45].

\section{STOMA SITE LOCATION IN RELATION TO THE RECTUS ABDOMINIS MUSCLE}

In selecting the stoma site location, it is necessary to determine its location in relation to the rectus abdominis muscle [16]. This area may be identified when the patient is lying on his or her back raises the head or leg, and coughs or laughs several times $[18,42]$. Performing the ostomy in this area may help prevent peristomal hernia or stoma prolapse in the postoperative period.

The location of the stoma site should be determined at one-third of the diagonal distance between the navel and the iliac spine - left for a colostomy, and right for an ileostomy [18]. This is particularly important to ensure the sealing of stoma appliances and to eliminate problems with its maintenance and use [44]. For this reason, the areas near the navel, hip bone, costal arch, groin, and waist should be avoided when selecting the stoma site [15, 42, 43].

\section{INDIVIDUAL APPROACH TO EACH PATIENT}

When selecting the site for an intestinal stoma, an individual approach should be applied to each patient $[45,46]$. In determining the stoma location, it is important to consider the patient's age, visual perception, body shape, sagging breasts, fitness level, finger dexterity, laterality, profession, lifestyle, preferred clothing, and any related religious considerations $[13,15$, 16, 42].

In obese patients, patients with severe sight impairments, patients in wheelchairs, or in those using walking frames, the future stoma site should be marked on the tip of the abdomen. In this site, the stoma is more easily accessible and visible $[15,18]$. In highly obese patients, preventive measures require selection of the stoma site in an upper quadrant of the abdomen, where the layer of tissue is thinner than in the lower quadrants. Performing an ostomy in this area is easier for the surgeon and may reduce the complications that could occur as a result of stoma prolapse in the typical location [42, 43]. In highly obese patients, the stoma may be created in the navel, following its resection [7].

A stoma should not be located in a place where the patient wears suspenders. It should be located in a way that makes it easily accessible to patients who wear special clothing or uniforms daily. The type of job performed by the patient must be considered (manual labour or white-collar work, sitting or standing). It is also important to determine whether the patient does sports (if so, then which ones) and is 
physically active. It is a further challenge to determine the location (locations) of the intestinal stoma in patients with other problems, those who wear traditional attire, or those who perform religious rituals during the day. In addition, Muslim patients traditionally do not use their right hand to remove impurities, which may be significant for stoma self-care and maintenance [42].

For other patients the future stoma location should be marked to ensure optimum visibility and accessibility for the patient. The literature provides no specific guidelines in this regard, and each clinical case is handled individually. An ethical approach to patients is absolutely required in all the steps involved in stoma siting [42, 45, 46].

\section{STOMA SITE LOCATION ON HEALTHY SKIN AND ON THE FLAT SURFACE OF THE ABDOMEN}

Following initial identification of the future intestinal stoma site, the surface of the abdominal walls should be examined. The skin on the patient's abdomen in the area of the target stoma site should be healthy, and its surface should be flat [18, 42]. A stoma should be located at least $4 \mathrm{~cm}$ from the surgical wound, scars, abdominal folds, other skin irregularities, and places of lesioned skin [15-18, 42]. Inappropriate stoma sites usually result in incorrect sealing or stoma appliance adhesion issues. This results in the leakage of intestinal contents into the surgical wound and on the skin, leading to serious surgical and dermatological complications [18, 27].

\section{SELECTING MULTIPLE POTENTIAL STOMA SITES}

If the intestinal stoma site is to be selected in a patient who also has a urostomy, or there is a probability that this type of stoma will be created, it is necessary to ensure that these 2 stomata will not be located in the same plane. A safe distance between them allows their appropriate protection, maintenance with stoma appliances, and correct location of an ostomy belt, if required [15, 42, 44]. If the number, type or eventual location of the stoma is uncertain, it is recommended to mark multiple sites and to rank them in order of specific preferences relating to a given clinical scenario. Depending on the course of the surgery, the surgeon will then be able to select the best site for creating the intestinal stoma $[15,18]$.

\section{MARKING THE STOMA SITE(S)}

After the patient accepts the selected location for creating the intestinal stoma and it is approved by the physician, the site should be marked with a surgical marker. If the stoma site is marked with a regular marker, the place should be protected against washing off when bathing by applying a transparent occlusion foil [15, 42]. The specified stoma site can also be marked using a thin needle, ensuring that all infection prevention procedures are observed $[15,18]$. Finally, it is crucial to remember that any previous markings that are now considered inappropriate must be removed [42].

\section{CLINICAL BENEFITS RESULTING FROM PREOPERATIVE STOMA SITE SELECTION}

Selecting an optimal intestinal stoma site affects the course of the surgery and contributes to its successful performance by the surgeon. With a correctly created and located stoma, there is a lower percentage of postoperative complications, rehabilitation is more effective, and patients' quality of life is higher [7-9, 12, 27, 47-59]. A properly created and located stoma eliminates unexpected complications, such as those that might occur after a poorly created and located stoma. Patients with a good stoma, who are well-educated, in a good general condition, well-nourished, receiving appropriate stoma care, and using proper stoma equipment will experience no serious postoperative or skin-related complications, and enjoy better health, hygiene, and a sense of cleanliness. Hospital visits are limited to a minimum, reducing healthcare costs [13]. Therefore, the procedure of intestinal stoma siting should be mandatory in clinical practice, and this view has been supported by both Polish and international authors [7-9, 12, 19, 20, 47-60].

Photographic documentation is presented in Figures 1-6.

\section{SUMMARY OF THE KEY PRINCIPLES OF INTESTINAL STOMA SITING}

1. The intestinal stoma site can be selected by a physician or nurse (male nurse), with active participation from the patient. The physician and nurse (male nurse) should cooperate with each other in this respect [8-18].

2. The intestinal stoma site should be determined in lying, standing, sitting, and bent-forward positions [14, 15, 18, 42].

3. The stoma site should be selected in relation to the rectus abdominis (abdominal) muscle. This contributes to reducing the percentage of postoperative complications.

4. The location of the stoma site should be determined at one-third of the diagonal distance between the navel and the iliac spine - left for a colostomy and right for an ileostomy.

5. The stoma site should be located far from the navel, hip bone area, costal arch, groin, and waist [15-18, 42-44]. 


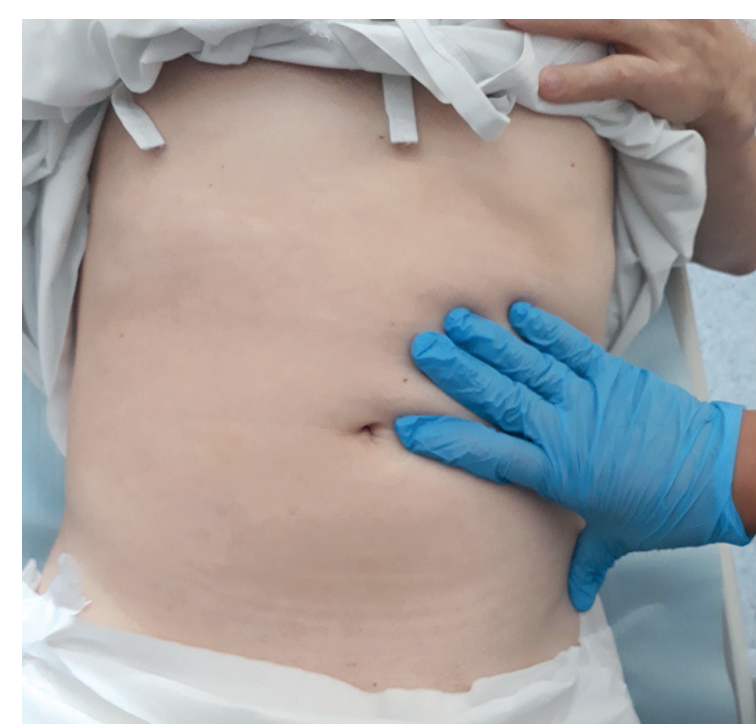

Figure 1. Stoma site marking in the lying position

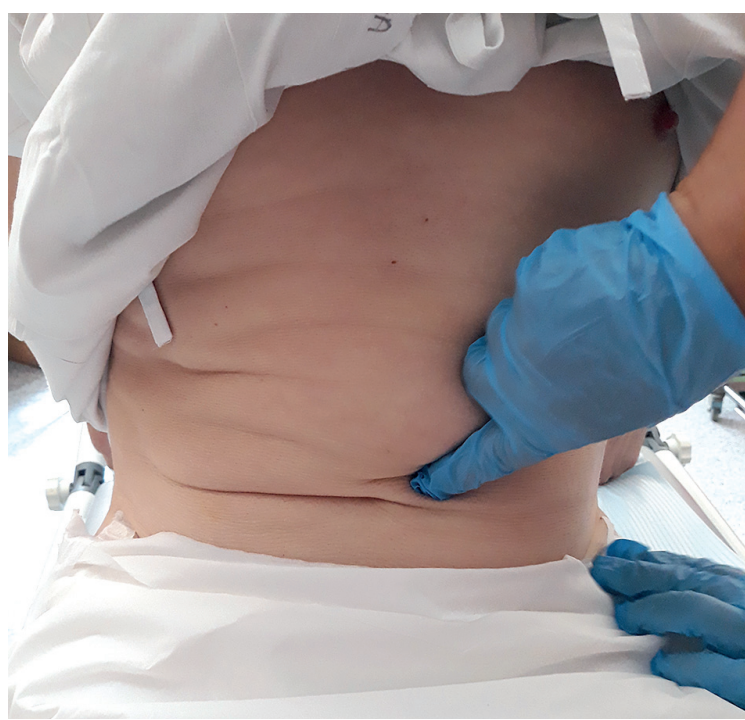

Figure 3. Stoma site marking in the sitting position

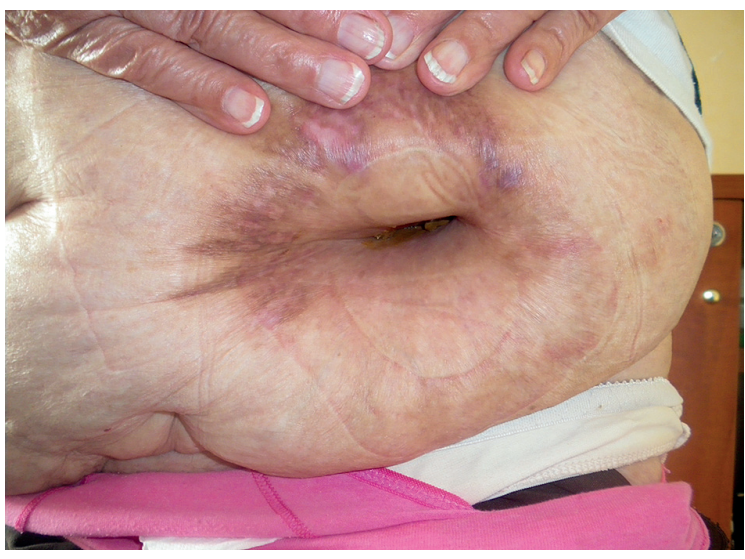

Figure 5. A patient without preoperative intestinal stoma site marking (improper abdominal wall stoma)

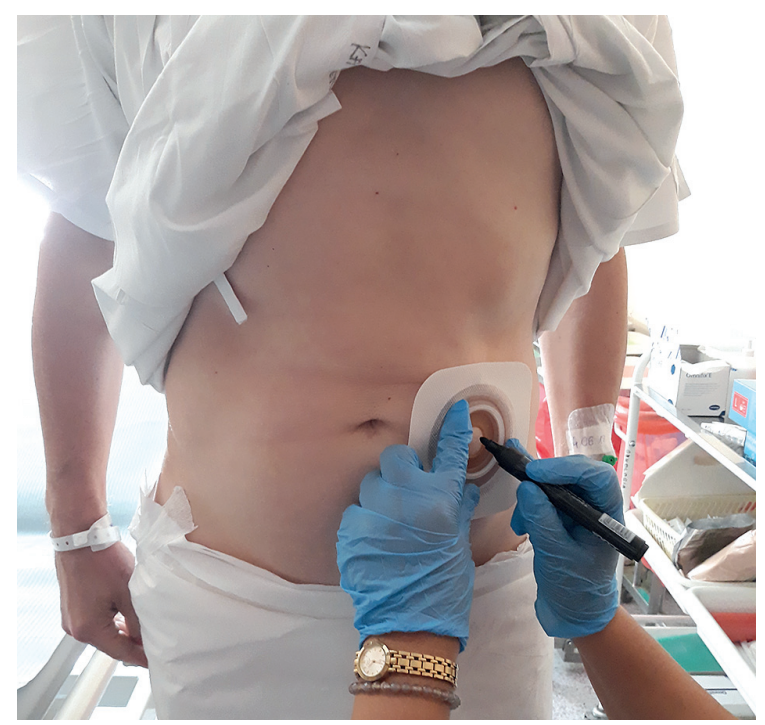

Figure 2. Stoma site marking in the standing position

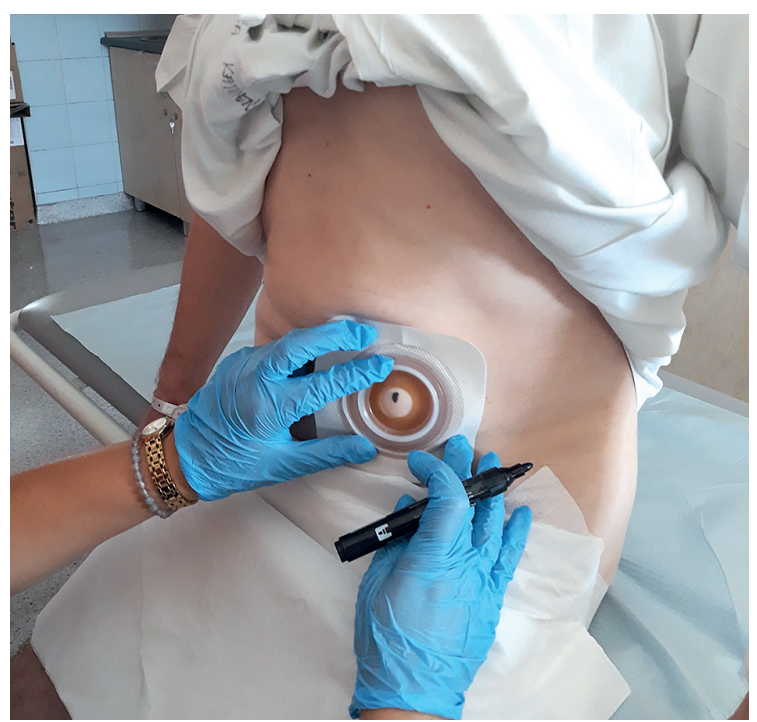

Figure 4. Stoma site marking in the sitting position

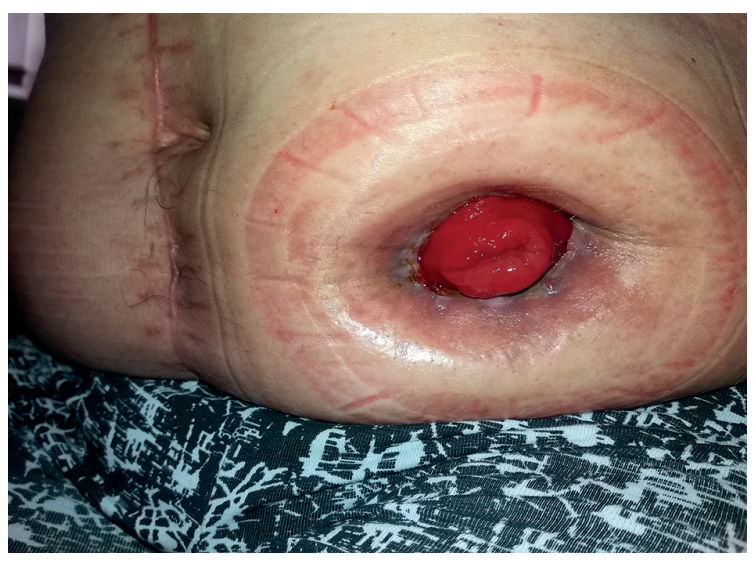

Figure 6. A patient without preoperative intestinal stoma site marking (improper abdominal wall stoma)

The photographs were taken by Anna Śmiżewska - a stoma care nurse, in a Stoma Care Clinic, Provincial Specialist Hospital in Wroclaw. 
6. In determining intestinal stoma location, it is important to consider the patient's visual perception, body shape, sagging breasts, fitness level, finger dexterity, laterality, profession, lifestyle, preferred clothing, and potential related religious considerations. A personalised approach to every patient should be applied [13, 15-18, 42-46].

7. Stoma site location should be marked on healthy skin and on a flat surface of the abdomen. This is significant for the correct maintenance of stoma appliances.

8. A stoma should be located at least $4 \mathrm{~cm}$ from the surgical wound, scars, abdominal folds, other skin irregularities, and lesioned skin sites [15-18, 27, 42, 44].

9. If the number, type, or eventual location of the stoma(ta) is uncertain, it is recommended that multiple sites be selected and ranked in order of preference.

10. It is recommended that the final site (sites) of intestinal stoma(ta) should be marked with a surgical marker pen [15, 18, 42, 44].

\section{CONCLUSIONS}

Preoperative intestinal stoma siting helps to form the stoma in an optimum abdominal-wall location. This procedure is recommended by leading authors and researchers concerned with intestinal surgery. Correct stoma location and professional patient care are some of the key factors limiting postoperative problems (postoperative, skin-related, and psychological complications). Patients with a well-located and uncomplicated intestinal stoma can enjoy a relatively high quality of life.

\section{Disclosure}

The authors declare no conflict of interest.

\section{References}

1. Hyland J. The basics of ostomies. Gastroenterol Nurs 2002; 25: 241-244.

2. Jawień A, Banaszkiewicz Z. Stomie jelitowe. Przew Lek 2003; 10: 89-92.

3. Szczęsny W, Siewkowska M, Dąbrowiecki S, et al. Stomia jelitowa - podział i powikłania. Probl Pielęg 2013; 21: 260265.

4. Chrostkowska I, Wanot B, Biskupek-Wanot A, et al. Exteriorisation of intestinal stoma as a result of intestional cancer disease. Scient J Pol Univ 2017; 25: 134-145.

5. Michalak S, Cierzniakowska K, Banaszkiewicz Z, et al. Evaluation of patients adjustment to living with stoma. Pielęg Chir Angiol 2008; 3: 91-98.

6. Pachocka L, Urbanik A. Stomia jelitowa - epidemiologia, rys historyczny, zasady wyłaniania i rodzaje stomii jelitowych. Probl Hig Epidemiol 2014; 95: 586-590.

7. Szczepkowski M. Dobra stomia. Post N Med 2006; 5: 240-250.

8. Bielecki K, Kózka M. Model opieki nad pacjentem ze stomią. Przew Lek 2002; 5: 89-91.
9. Cierzniakowska K, Szewczyk MT, Banaszkiewicz Z, et al. Profesjonalna opieka nad osobą ze stomią w Polsce. Pielęg Chir Angiol 2010; 2: 35-39.

10. Leyk-Kolańczak M, Książek J, Piotrkowska R. Realizacja opieki stomijnej w Polsce w opinii pielęgniarek. Probl Pielęg 2017; 25: 20-28.

11. Krokowicz P, Gmerek $Ł$, Horbacka K. Historia opieki stomijnej. In: Stomia. Prawidłowe postępowanie chirurgiczne i pielęgnacja. Termedia Wydawnictwa Medyczne, Poznań 2014; 21-22.

12. Cierzniakowska K, Cwajda-Białasik J, Szewczyk MT, et al. Specjalistyczna opieka pielęgniarska nad chorym ze stomią jelitową w świetle badań. Pielęg Chir Angiol 2008; 2: 39-43.

13. Cronin E. Stoma siting: why and how to mark the abdomen in preparation for surgery. Gastrointestinal Nurs 2014; 12: 12-19.

14. Stelton S, Zulkowski K, Ayello EA. Practice implications for peristomal skin assessment and care from the 2014 World Council of Enterostomal Therapists International Ostomy Guideline. Adv Skin Wound Care 2015; 28: 275-284.

15. Wasserman MA, McGee MF. Preoperative considerations for the ostomate. Clin Colon Rectal Surg 2017; 30: 157-161.

16. Stelton S. Challenging Stoma Site Selection. WCET Journal 2018; 38: 36-37.

17. Khan MA, Bhat MA, Magray JA, et al. Stoma site selection: why and how. Ann Surg Edu 2019; 1: 1004.

18. Kwiatt M, Kawata M. Avoidance and management of stomal complications. Clin Colon Rectal Surg 2013; 26: 112-121.

19. Szczepkowski M. Stomia jelitowa - wyzwanie nie tylko dla chirurga. Proktol Lek Rodz 2004; 5: 57-69.

20. Cierzniakowska K, Szewczyk M, Cwajda J, et al. Wybrane procedury w opiece okołooperacyjnej nad chorym ze stomią. Przew Lek 2005; 2: 87-92.

21. Pyć M. Standard opieki pielęgniarskiej nad chorym ze stomią. MONZ 2008; 14: 105-115.

22. Szewczyk J, Bajon A. Nursing care in perioperative period in patients with intenstinal stomia exposure. Pol Merk Lek 2009; 26: 575-578.

23. Kózka M, Bazaliński D, Cipora E. Przygotowanie chorego z przetoką jelitową do samoopieki z uwzględnieniem powikłań dermatologicznych i chirurgicznych. Pielęg Chir Angiol 2010; 2: 57-62.

24. Kózka M, Bazaliński D. Zastosowanie systemu wspierającouczącego w opiece nad pacjentem z przetoką jelitową. Probl Pielęg 2010; 18: 337-341.

25. Lewandowska I, Kowalik J, Kopański Z, et al. Opieka nad pacjentem ze stomia jelitową. J Public Health 2011; 2: 9-13.

26. Borowska-Szczepuchowska K, Rezmerska L. Jakość opieki medycznej w opinii chorych ze stomią jelitową. Innow Piel N Zdr 2017; 2: 52-67.

27. Baykara ZG, Demir SG, Karadag A, et al. A multicenter, retrospective study to evaluate the effect of preoperative stoma site marking on stomal and peristomal complications. Ostomy Wound Manag 2014; 60: 16-26.

28. Piaszczyk DL, Schabowski J. Problemy medyczne i społeczne pacjentów ze stomią należących do POL-ILKO. MONZ 2014; 20: 384-389.

29. Cakir SK, Ozbayir T. The effect of periperative stoma site marking on quality of life. Pak J Med Sci 2018; 34: 149-153.

30. Kamiński F, Dadan J, Majewska G. Źle umiejscowiona stomia - konsekwencja operacji czy pierwsze powikłanie chirurgiczne? Nowa Med 2016; 54-60.

31. Gaćkowska K, Paluszkiewicz P. Powikłania skórne stomii jelitowej. Pielęg Chir Angiol 2021; 1: 1-7. 
32. Carne P, Robertson G, Frizelle F. Author's reply: Parastomal hernia (Br J Surg 2003; 90: 784 793). Br J Surg, 2003; 90: 1306-1307.

33. Banaszkiewicz Z, Szewczyk MT, Jarmocik P, et al. Miejscowe powikłania kolostomii u osób w wieku podeszłym - badanie retrospektywne. Wspolczesna Onkol 2006; 10: 245-249.

34. Israelsson LA. Parastomal hernias. Surg Clin North Amer 2008; 88: 113-125.

35. Krishnamurty DM, Blatnik J, Mutch M. Stoma complications. Clin Colon Rectal Surg 2017; 30: 193-200.

36. Banaszkiewicz Z, Tojek K, Jarmocik P, et al. Powikłania gojenia rany po wyłonieniu stomii. Przew Lek 2004; 7: 102-104.

37. Kołodziejczak M, Ciesielski P, Kosim A. Postępowanie terapeutyczne w przypadku powikłań skórnych oraz trudno gojących się ran wokół stomii. Nowa Med 2013; 2: 54-57.

38. Banaszkiewicz Z, Cierzniakowska K, Jarmocik P, et al. Zmiany skórne wokół stomii. Leczenie Ran 2013; 10: 1-6.

39. Kózka M, Bazaliński D, Jakubowski K, et al. Determinanty funkcjonowania psychospołecznego osób z przetoką jelitową. Pielęg Chir Angiol 2010; 4: 123-129.

40. Cierzniakowska K, Kozłowska E, Szewczyk MT, et al. Jakość życia pacjentów z wyłonioną stomią jelitową. Pielęg Chir Angiol 2013; 4: 142-147.

41. Dziedzic B, Sienkiewicz Z, Leńczuk-Gruba A, et al. Jakość życia pacjentów z wyłonioną stomią jelitową. Pielęg Chir i Angiol 2019; 3: 100-106.

42. Salvadalena G, Hendren S, McKenna L, et al. WOCN society and ASCRS position statement on preoperative stoma site marking for patients undergoing colostomy or ileostomy surgery. J Wound Ostomy Continence Nurs 2015; 42: 249-252.

43. Roveron G, De Toma G, Barbierato M. Italian Society of Surgery and Association of Stoma Care Nurses Joint position statement on preoperative stoma siting. J Wound Ostomy Cont Nurs 2016; 43: 165-169.

44. Burch J. Research and expert opinion on siting a stoma: a review of the literature. Br J Nurs 2018; 27: 4-12.

45. Cronin E. What the patient needs to know before stoma siting: an overview. Br J Nurs 2012, 21: 1234-1237.

46. Kobielska G, Posłuszna-Owcarz M. Oczekiwania pacjentów stomijnych wobec wsparcia oferowanego przez pracowników służby zdrowia. Pielęg O Dług 2016; 2: 24-31.

47. Glińska J, Hebda A, Dziki A. Wpływ opieki pielęgniarskiej na jakość życia pacjentów ze stomią jelitowa. Proktologia 2005; 6: 232-242

48. Bazaliński D, Barańska B, Cipora E. Stomia jelitowa nie musi być przyczyną niepełnosprawności. Medycyna Rodz 3 2006; 3: 58-63.

49. Michalak S, Cierzniakowska K, Banaszkiewicz Z, et al. Ocena przystosowania się chorych do życia ze stomią jelitową. Pielęg Chir Angiol 2008; 3: 91-98.

50. Person B, Ifargan R, Lachter J, et al. The impact of preoperative stoma site marking on the incidence of complications, quality of life, and patient's independence. Dis Colon Rectum 2012; 55: 783-787.

51. Ławnik A. Rehabilitacja pacjentów ze stomią jelitową. MONZ 2015; 21: 84-87.

52. McKenna LS, Taggart E, Stoelting J, et al. The impact of preoperative stoma marking on health-related quality of life: a comparison cohort study. J Wound Ostomy Continence Nurs 2016; 43: 57-61.

53. Arolfo S, Borgiotto C, Bosio G, et al. Preoperative stoma site marking: a simple practice to reduce stoma-related complications. Tech Coloproctol 2018; 22: 683-687.
54. Gök AFK, Özgür İ. Altunsoy M, et al. Complicated or not complicated: Stoma site marking before emergency abdominal surgery. Ulus Travma Acil Cerrahi Derg 2019; 25: 60-65.

55. Abbas KS, Madbouly KM, Abbas MS, et al. Effect of preoperative stoma site marking on early and late outcomes of intestinal stoma creation. Egypt J Surg 2019; 38: 722-728.

56. Kugler CM, Breuing J, Rombey T, et al. The effect of preoperative stoma site marking on risk of stoma-related complications in patients with intestinal ostomy - protocol of a systematic review and meta-analysis. Systematic Reviews 2021; 10: 1-8.

57. Woźniak M, Posłuszna-Owcarz M. Jakość życia pacjentów z wyłonioną stomią jelitową. Pielęg O Dług 2018; 2: 40-50.

58. Ambe PC, Kurz NR, Nitschke C, et al. Intestinal ostomy: classification, indications, ostomy care and complication management. Dtsch Arztebl Int 2018; 115: 182-187.

59. Hsu MY, Lin JP, Hsu HH, et al. Preoperative stoma site marking decreases stoma and peristomal complications: a meta-analysis. J Wound Ostomy Continence Nurs 2020; 47: 249-256.

60. Campos FG, Nahas SC, Cecconello I. The life of John Cedric Goligher (1912-1998) revisited. J Medical Biography 2016; 24: 380-383. 